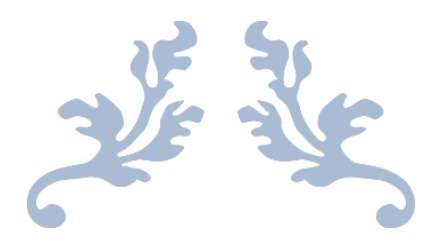

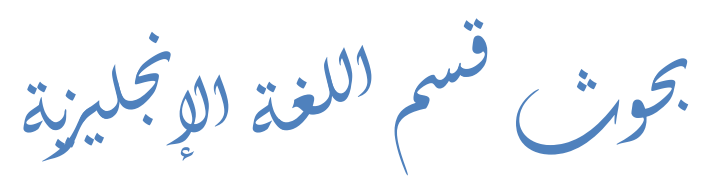




\title{
Justice and Human Rights in El Saadawi's plays: Isis (1985) and Al Zarqaa (2006)
}

\author{
العدالة وحقوق الانسان فى مسرحتى نوال السعداوى: ايزيس والزرقاء
}

Galal Ibrahim Baligh Yusuf

\begin{abstract}
الملخص
تعد نوال السعداوي ناشطة نسوية وليبرالية ومفكرة. وتبرهن في مسرحياها ، على ارتباط الصحة بالاقتصاد والسياسة والدين والتاريخ والجنس والثقافة. وتدور الفكرة الأساسية التى تتناولها كتابات السعداوي حول الارتباط بين تحرير الإنسان وتحرير الوطن ثقافيًا واجتماعيًا وسياسيًا. وتستخدم الكاتبة نفسها وبشكل متكرر مفهوم حقوق الإنسان والمفاهيم الأخرى ذات الصلة مثل "العدالة" و "الحرية" و "الكرامة". وتناقش نوال السعداوي في مسرحية إيزيس العديد من القضايا الاجتماعية الهامة التي يعتبرها كتّاب آخرون من المحرمات. حيث تعرض وتنتقد العديد من القضايا الاجتماعية والسياسية والثقافية المعاصرة والتى تبرز أن الفقر والجهل من الأمراض الاجتماعية الكارثية. والسعداوي لا تولي اهتماما لحقوق المرأة فحسب ، بل هتم أيضا بحقوق الفقراء والمهمشين في المجتمع ، وخاصة حقوق العمال. وتعتبر مسرحية الزرقاء لنوال لسعداوي من أفضل مسرحياتها التي تتناول حقوق العمل و العمال في الوطن العربي وخاصة في مصر ـ ويبدو أن حقوق الإنسان تربط السعداوي بمصر التي تشعر بالغربة عنها بسبب أفكارها المثيرة للجدل.

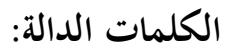
السعداوي- إيزيس- الزرقاء - العدالة- حقوق الاسان- حقوق المرأة - حقوق العمال
\end{abstract}

Abstract:

Nawal El Saadawi is a feminist, liberal activist and thinker. In her plays, she links health to economics, to 
politics, to religion, to history, to sexuality and to culture. The main idea of El Saadawi's writings revolves around the link between the liberation of human beings and the liberation of the homeland, in terms of cultural, social and political aspects. She herself makes a frequent use of the concept of human rights and related notions such as "justice", "Freedom" and "dignity". In Isis, El Saadawi discusses many critical social issues that other writers consider taboos. She exposes and criticizes many social, political and cultural contemporary issues. She shows that poverty and ignorance are disastrous social diseases. El Saadawi does not only pay attention to the women's rights but also to the poor and marginalized people in the society, especially the rights of workers. El Saadawi's Al Zarqaa is considered one of her best plays which deals with the rights of the workers in the Arab world, especially in Egypt. Human rights seem mostly to connect El Saadawi to Egypt from whom she feels estranged because of her controversial ideas.

\section{Key Words:}

El Saadawi- Isis- AlZarqaa - justice - human rightsWomen's rights- workers' rights. 
Nawal El Saadawi (1931 -2021) was born in Egypt to middle - to- lower- class from small rural Kafr Tahla village outside Cairo. She graduated from the University of Cairo Medical College in 1955, specializing in psychiatry. She is a feminist, renowned Arab writer, liberal activist and thinker. She has been one of the most controversial literary figures in Arab contemporary literature. She has published nearly 50 plays, novels and short story collections, reprinted and reissued in Arabic, and are widely read in her country and all Arab countries. El Saadawi has achieved widespread international recognition after the translation of her work into over thirty languages including English (Amireh,216). In her works, she links health to economics, to politics, to religion, to history, to sexuality and to culture. El Saadawi defends the cause of human rights, especially "women's rights" and "poor's rights" in the Arab world, and more specifically in the Egyptian society. She refuses to avoid the controversial issues such as prostitution, domestic violence and religious fundamentalism.

Brinda Mehta describes El Saadawi as "one of the most... outspoken defenders of human rights from the Arab World," which Mehta concludes translates into a straightforward 
"humanism" ( 152, 3). El Saadawi has welcomed the label of a "human rights activist". The main idea of El Saadawi's writings revolves around the link between the liberation of human beings and the liberation of the homeland, in terms of cultural, social and political aspects. She herself makes a frequent use of the concept of human rights and related notions inscribed within the term, such as "justice". "freedom" and "dignity".

Women have the right to freedom in economic, political, social, educational and all other affairs. Khadidiatou Gueye states that " El Saadwai's subversive writing shapes and is shaped by a resolute struggle against injustice". Gueye quotes El Saadawi, saying " writing is like killing, because it takes a lot of courage ... because you are killing ideas, you are killing injustices, you are killing systems that oppress" (162). Barbars Harlow' calls El Saadawi, a writer of "resistance literature " (137). She has fought on all economic, social, cultural, racial, religious, or political fronts:

In countries of the South the issue of human rights raises the question, How far can we talk of human rights without a new conception which extends them to the economic, social, cultural, racial and religious fields as well as to women and 
youth? How far can the present limited approach go? Does it no need to expand, to interest much wider sections of the population in action for human rights?(El Saadawi,1992)

El Saadawi's decision to write about women is influenced by her faith in the feminist movement which renders women "more aggressive in searching for their own history, demanding their rights and pursuing equality" (2009:24). She states, "For me, feminists cannot oppose the oppression of women by men and accept or tolerate the oppression and exploitation of whole nations and cultures". She adds "Everything is political: food, clean water, the way you love, the way you're loved, Survival is certainly political" (Gharbi,8).

Isis expresses El Saadawi's view that the way to empower resistance is through " unity in diversity by breaking down barriers built on discrimination ( by gender, class, race, religion, ... etc)" (Genette, 19).

El Saadawi asserts: "If I don't tell the truth ....I don't deserve to be called a writer" (World Literature Today, January- February 2008). In the Reader, she says "I write to emerge from the dark to the light of knowledge, from the 
chaos of the unjust world to a new world of justice, freedom and love" (9). In Isis, the first section from Scene 3, Act 1, is a conversation between Isis and Maat (the personification of order, truth, and justice) in which they discuss how to respond to Ra's despotic regime. The most fascinating part of this discussion is the goddesses' argument about the writer's place in society. Maat, an author, claims that her job is either to record what she sees or to engage in creative writing that is unconnected to reality. Politics is not her concern.

Isis rejects this position, maintaining that every written word is a stance and that silence only serves to condone injustice. Maat is indicative of many Arab women writers who, feeling that feminism is an extreme Western idea, simply contents them with "neutrality." Isis, on the other hand, subverts patriarchal limitations placed on women by maintaining the power of feminist writing and art:

ISIS: A word, when you write it down, is no longer neutral because a word is a stance . You think that you are neutral because you do not stand with Set or against him. But your "neutral" position, ultimately, sides with Set. You know that he is oppressing and killing, and [yet] you stay silent. And this silence of yours helps him to continue this oppression and 
murder. You are not neutral, as you imagine. You are aligned with Set. Aligned with him in a negative and weak manner. Your position is alignment and not neutrality $(\mathrm{I}, \mathrm{iv}, 44)$

Isis (1985) takes its title from a popular everlasting ancient Egyptian myth, Isis and Osiris. The myth consists of three parts: the death and resurrection of Osiris, birth and childhood of Horus and the conflict between Horus and Set. Osiris is the son of the earth god Geb and the sky goddess Nut. The primary focus of the myth is on Osiris's death at the hands of Set, his brother. The various versions of the myth vary in identifying the motive of Set's enmity against Osiris.

The myth has been adapted by various writers. In modern Egyptian literature, the myth is adapted into another play with the same title Isis (1955) by Tawfiq El Hakim. El Saadawi is motivated to write her play Isis after she has watched El Hakim's play. El Saadawi criticizes El Hakim's portrayal of Isis not as a goddess but as a dutiful wife who sacrifices all her needs and her possession for her husband to ensure his well-being. This representation corresponds to the ancient myth. 
El Saadawi states that El Hakim " transforms Isis into a silent figure unable to participate in the debates among philosophers and writers and ready to forfeit her values for the sake of her husband" $(2009,12)$. In her introduction to Isis, El Saadawi elaborates her point of view of the goddess Isis:

Many writers have written about Isis, the ancient Egyptian goddess, but no one credits her as a teacher and inventor of agriculture, bread making and writing, nor do they portray her accurately as a figure who had a philosophy, values and religion [...]. They have formed a mundane image of her, based on her loyalty to her husband and her role as a mother (11-12)

El Saadawi introduces the myth in a different form to criticize her contemporary society. Bagnole argues that El Saadawi's decision to write about the goddess Isis in particular is influenced by her faith in the feminist movement which renders women "more aggressive in searching for their own history, demanding their rights and pursuing equality" (24). El Saadawi draws on the goddess of her own background that is considered a "part of the writer's history and a figure familiar to her intended readers" ( 24). 
Mikhail Bakhtin argues that a work of art is open to new and various interpretations of both current and future readers according to their social and cultural contexts (4). El Saadawi's adaptation differs in some respects from the original story which is set in a remote indefinite time, in ancient Egypt in a world occupied only by gods and goddesses, with conflicts among them. The world of the play is inhabited by both deities and human beings. The gods and goddesses rule the kingdoms of earth and sky.

The story begins with the sun god Ra proclaiming his autocratic rule in heaven and on earth after defeating Nut, the goddess of the sky and wife of Geb, god of earth. Ra is essentially modeled after Arab dictators who demand absolute submissiveness of their subjects and punish any resistance with fire and fury.

A new world order begins, an "era of supreme men , ..., the era of strong male rulers. Ra, the god of the sun, claims himself the ruler of the sky, announcing "Gone is the time of many rulers and authorities on earth or in the sky" $(1, i, 35)$. The era of goddess Nut's regime is denounced as being" the era of the human gods" unlike the era of Ra which marks " the start of the inhumane gods" $(1, \mathrm{i}, 33)$. 
Set, who is Isis and Osiris's brother, sides with Ra and requests the kingdom of earth as his prize. He must first get rid of his brother Osiris, the current king and husband of Isis, which he does easily and ruthlessly while also hoping to win Isis's heart. Isis, dejected and distraught after her husband's murder, resurrects Osiris and produces a son (Horus) with him only to see him killed again by Set, who cuts his body into pieces and scatters them all over Egypt.

The play ends with Set being accused of murder in a public court. Horus exacts revenge by cutting off Set's testicles. Isis, because she is a merciful goddess, decides that punishment is enough and lets Set live..

El Saadawi denies that Isis is a deity who is endowed with omnipotence. El Saadawi introduces Isis as an ordinary woman who is endowed with sharp intelligence and knows well how to employ them. The army Chief depicts Isis as "the goddess of reason and wisdom" (1, IV, 61). Set says" when Isis decides to do something, nothing can stop her. She is solid like a rock... She possesses an extraordinary power" $(1, I V, 54)$.

Isis states that:"The law of justice is the law of people... The majority of the people" ( II, iv,102). El Saadawi declares "I 
used to praise freedom and justice, without which life would have no value" (1997:2).Isis calls people to put an end to a world in which injustice prevails and to move towards a world of justice and human rights.

In The Reader, El Saadawi mentions that we cannot speak about global injustice without speaking about inequality between countries, inequality between classes in each country, and inequalities are linked together in the patriarchal capitalist system that govern the world today (79). She adds:

Our world will change for the better by the power of collective will of united people fighting together to end all types of inequalities ( based on gender, religion, class, race, nationality, etc.).We together, globally and locally, men and women, can change this unjust capitalist patriarchal racist religious world to a better one. To do this we need to: Unveil our mind and unite glocally (globally and locally) (3).

The community justice program which is operated by local people as for example in the village of khibit near the shore of Al- Manzala .The procedures of community stated that Isis set up the rules of the community in order to 
maintain peace and administer the villagers in terms of justice which is clear in different forms.

El Saadawi views that the way to empower resistance is through " unity in diversity by breaking down barriers built on discrimination (by gender, class, race, religion... etc.)" (Genette, 19). Isis lives among common people helping "some male peasants in starting their irrigation" $(11, \mathrm{I}, 83)$. Maat, her sister, is assisting "some women in grinding the barley" (11, I, 83). Isis, Osiris and Horus "participate with peasant men and women in planting, watering, and building bridges on the Nile. They are all singing while they are collecting the white cotton from the bushes" $(11$, iii, 97). The peasants are "collecting the harvest, they sing for the light given to them" (11, iii, 97), indicating prosperity and abundance brought out by Isis.

Isis is a practical character. She works in harmony with the resources of nature to produce the utmost benefit in the various seasons of the year. She acts as an educator who tries to erase illiteracy of the commons as she "distributes pencils and teaches the group [of children] and her son Horus how to write" $(11, \mathrm{I}, 83)$. Isis's experience stands for every other woman's similar experience under the umbrella of an 
oppressive patriarchal system. Isis's experience should extend to every oppressed woman. The play includes various themes such as critiques of monotheistic religions, political regimes, tyranny and corruption.

In Isis, El Saadawi discusses many critical social issues that other writers consider taboos for she believes there is a close connection between "politics, economics, history, religion and morality"(Genette, 2). El Saadawi exposes and criticizes many social, political and cultural contemporary issues. She shows that poverty and ignorance are disastrous social diseases. She believes that the task of the writer is to tell the truth. She mentions "if I don't tell the truth, [...] I don't deserve to be called a writer" (2009: 55).El Saadawi calls writers not to be passive or silent in face of power:

ISIS. The man or woman writer who does not aim for justice is nothing but a whistle blowing air in cane pipes... The word is an opinion ... [when] you [a writer] know that he [a ruler] is brutal and an assassin and you stay silent, your silence supports him in continuing his cruelty and crimes. (I,iii,46). 
Gender discrimination against women is the most prominent issue that preoccupies El Saadawi. She compares the current inferior position of women within the Egyptian and Arab patriarchal systems with that of ancient Egypt. She comments:

If we delve more deeply into ancient Egyptian [life...], we will discover the humanistic elements that were prevalent in many areas of life. Women enjoyed a high status and rights, which they later lost when class patriarchal society became the prevalent social system. (1997: 29).

The nature of society presented in the play is patriarchal as Ra states" I decide the successor to the throne of the sky and the earth. The successor must be a male ... a man ... not a woman not a female. Gone is the era of women; the era of manlineness, courage, power, and fear has begun" (1, i, 34$35)$.

Maat informs Isis that in the reign of god Ra: "A woman is not even a human ... Nothing is left for her but to peel onions and bear children, like rabbits and cats" (I, iii, 44). Set states that" a woman is born to bear children and nothing else" (II, ii, 94). Similarly, the Army Chief mentions that "I, 
my Lord, do not comprehend any relationship with women except for rape" (I, iv, 64).

Women, like Isis, in this patriarchal system debate everything, love argument and philosophy, like to submit everything to rational reasoning and assessment, believe "that justice is above power, and peace is above war" (I, i, 32). They are dismissed as being feminists. They are considered inferior citizens. El Saadawi does not only prove discrimination against women, but also against the poor and the unprivileged. This is demonstrated in Isis's words "Darkness has spread everywhere... and discrimination has proliferated" (I, v, 71). Ra states "Gone is the period in which equality has spread among the weak and the strong, the sons of gods and the sons of people, men and women" (I, i, 29)

The High Priest expresses his class prejudice in his comment on Isis's rejection of any sacrifices offered to her temple: "Any job is an insult to me ... We priests do not work and we are not slaves. I am used to sitting in the temple and having food brought to me, to my feet" (II, I, 87). Isis's argument against this priest is a call for social justice and mercy:" People in this village are poor peasants who sell their eggs and cannot afford to eat them. They do not taste meat 
except on special occasions... How we ask them to offer us sacrifices, sir? (II, i, 85).

Isis points out that she and her family work with the people, "We plant and work to get our resources through our sweat" (II, I, 85). Isis calls for equality and denies any form of discrimination: "Our philosophy equalizes deities and humans, masters and slaves. There is no difference between one human and another, except through justice and mercy "(II, i, 85).

In her comment on the discrimination, El Saadawi states:"the political regime imposed the will of man upon women and imposed poverty and slavery upon the poor and destitute" (1997: 2). Bagnole states:

Isis is not only a play about a great goddess of the ancient world. It is a contemporary presentation of the many discriminating rules that control the daughters of Isis. It tells about the present leaders of the lands of Isis who refuse to grant women their basic rights and have transformed them into second- class citizens. These women suffer physical mutilation, violation and mental manipulation by selfassigned protectors who .... Are threatened by their [women's] freedom. (2009:25). 
Satire is the hallmark with which El Saadawi connects contradicting truths. In Isis, The reference to the rulers as gods may be a satirical indication. For example, Ra urges Set to announce to people that Ra does not "appear on earth and [his] dwelling is on the disc of the sun " (I,i,93). El Saadawi satirizes the hypocrisy of men of religion through the claim of the High Priest before Ra: You are capable, almighty god, of making men able to get pregnant and give birth (II, ii,92). In a satire for hypocrite men of religion, the Army Chief reveals that "god Ra does not accept a prayer bare like this... There is no prayer without slaughter and meat....There is nothing for free" (I, IV, 58). Isis, ironically, says about Ra, "I will offer him a calf and prevent his wickedness. He prefers a calf from an unjust leader to the virtue of a just sovereign" $(\mathrm{I}, \mathrm{v}, 75)$.

Also, El Saadawi satirically describes the tyrant rulers who know nothing about their true religion. Set asks his Army Chief, "Do you remember what we used to say when we would start to pray? My memory is burdened with the affairs of government and state and I forget" ( I, iv,57). The Army Chief responds, " It seems I have forgotten the words 
too, my lord... my brain is occupied with plans of war, which are many, without end" (I, iv, 57)

The ancient Egyptian myth of Isis and Osiris has been a master plot for much literary adaptations across genres, such as the play Isis by 1 El Saadawi. Throughout this play, she anatomizes her society and discusses many of its problems in an interesting manner. The play deals with a variety of topics and thematic concerns.

The various trends such as the rise of feminism and professions such as writers, singers, even instruments such as pencils and papers found in the modern age all indicate modernity. Most issues in the play belong to the modern world. Bagnole points out: "Isis is ... about hope for better governments and laws that grant women equal rights and allow them to become contributors and decision- makers in matters that will benefit them and their children and steer their societies in the right directions" $(2009,26)$. Through her actions, her behavior, her perseverance and determination, she creates the basis for a rightful society. She becomes the last resort for those who lost hope in their society. She becomes the place where wrong is righted. 
El Saadawi does not only pay attention to the women's rights but also to the poor and marginalized people in the society, especially the rights of workers. El Saadawi's $A l$ Zarqaa is considered one of her best plays which deals with the rights of the workers in the Arab world, especially in Egypt.

Many Arab countries fail to protect workers' rights. Human rights are the basic rights and freedom that every person in the world should be entitled to. They are based on core principles such as dignity, fairness, equality, respect and autonomy. Many of these rights help to protect everyone within the workplace as they have been incorporated into general employment law.

The countries should ratify all relevant international and regional human rights tools, including ILO Conventions 87 and 98. They should assure that labour rights can be exercised by everyone, regardless of type of work. The UN should integrate labour rights into all its programs, and ensure that workers' rights are protected.

In the class society of the modern, industrial age, the working class is called proletariat and the proletariats are 
members of the working class. The proletarian workforce was necessary and had to be maintained with minimal living conditions. The Proletariat is the lowest or one of the lowest economic and social classes in a society. In postmodern society the poor are responsible for their own poverty. The rich isolate themselves in private systems of security.

The middle class which encompasses employed workers living in permanent anxiety and demands the distinction among them should begin to fade. In the absence of human rights, especially the rights of labours, many workers are fired or obliged to leave their work when they suffer from diseases. The workers, who are unskilled, badly paid, overworked, and miserably housed lack many of their rights as human beings.

Marxist theory considers the proletariat to be oppressed by capitalism. This oppression gives the proletariat common economic and political interests that transcend national boundaries. Marx believed that capitalism contained the seeds of its own destruction. In this play the world order is similar to El Saadawi's description of the modern world: " we are dominated or governed by one global system which is now called the New World Order". She goes on to warn that: 
If capitalist relations continue to govern the major part of our world, must it be the most aggressive and reactionary forces that hold the upper hand, those built on war, on military production, on the arms race, on racial, ethnic, sexual and religious discrimination, on destruction of the natural environment, pollution and imbalance of the ecosystem, on master- slave relations between countries and peoples of the south [the so- called developing world] and countries and peoples of the north [the so-called first world] ( 1997:30]

Hence, the proletarian literature is derived. It may comment on political and social events, and is frequently seen as an instrument to promote social reform or political revolution among the working classes. Proletarian literature is created especially by socialist authors. It is about the lives of poor. The intention of the writers of proletarian literature is to lift the workers from the slums, by inspiring them to embrace the possibilities of social change or a political revolution.

Scholarship on proletarian literature is unified by a Marxist approach to themes that have shaped literature from realism forward to contemporary multiculturalism. As an economic category the proletariat was distinguished 
in Marxian literature from the poor and working classes. The term proletariat was distinguished from the working class as a generic term. The former referred to those engaged in industrial production, whereas the latter referred to all who must work for their living and who received wages or salary, including agricultural labourers and white-collar workers. The proletariat as described by Marxists was usually living in poverty.

El Saadawi makes it clear that she does not belong to any ideology or class. She states:

The most important characteristic of my work is that I don't separate off the neocolonial machine - international politics - from the family and the personal lives of my characters ... even some of the leftist groups in Egypt accuse me of being pro- Western, but that is because I criticize their silence about gender when considering class. Meanwhile, the Right calls me a communist because I link class and patriarchy! And the religious fanatics call me an atheist because I'm critical of religious hypocrisy and because I say we need a real Islam, areal religion - and that's justice. I didn't learn this sense of justice from the West, I learned it 
from my illiterate grandmother, a peasant who never read the Koran”. (Hitchcock ,174)

The proletarian play is a subgenre of the drama, written by reformer dramatists to discuss the human rights for the workers. Sometimes, it is synonymous with the workingclass drama and socialist drama. In the class society of the modern, industrial age, a proletarian workforce was necessary and had to be maintained with minimal living conditions. In postmodern society the poor are responsible for their own poverty. The rich isolate themselves in private systems of security. The middle class which encompasses employed workers living in .

Many Arab countries fail to protect workers' rights. It is written in an easy and colloquial dialect. The idea of the play is an old one that discusses the lives of people in the lowest strata and on the margins of society, revealing their hardships, humiliations, and brutalization and sheds light on how occupying a high position changes or affects the morals and principles of the people.

El Saadawi's Al Zarqaa is considered a proletarian play and one of her best plays which deals with the rights of the 
workers in the Arab world, especially in Egypt. The play borrows its title from Al Zarqaa disease carried by a cargo of rabbits imported from Australia. The disease found its way among the poor and marginalized workers who work hard in a worn out factory to earn their living.

The workers work under bad conditions. They lack the means of protection against diseases. Workers need protection now more than ever. It is really important to recognize that human and labour rights are inseparable. Labour rights are human rights, and the ability to exercise these rights in the workplace is prerequisite for workers to enjoy a broad range of other rights, whether economic, social, cultural, political or otherwise.

In Al Zarqaa, El-Saadawi conveys to us the issue of authority control over the working class / proletariat. This issue is portrayed as a theatrical dialogue that includes a group of people, the most prominent of whom is Elwali who exercises his authority over the workers:

El Wali represents the army, police, detective, money, science, art, freedom, air, water, and eating. Our eating and our children's eating and every need in our lives. The mad is 
the only person who can wrestle with all this power, as if he is wrestling with nature completely ( $\mathrm{I}, \mathrm{v}, 35$, my translation)

The workers are unknown and negative characters. They do not play any positive role in their life or in their factory. El Saadawi do not mention the name of any worker in the play except the names of deceased workers such as Mohammed Ali and Metwalli who died as a result of the disease. The workers are prototypes of the marginalized people in their society. These workers suffer during their life and after death. They lack the social protection umbrella. For example, they are obliged to collect money to help the family of each worker when he dies because his pension is not enough.

The workers have contracted Al Zarqaa disease and four workers died one after the other in one month. They had the same symptoms: blue lips and dry cough. Hence the disease acquires its name. Al Zarqaa is an infectious disease and is transmitted by rabbits to workers within three days and has no cure. The spreading of the disease is slow, but it may last for years. They can be protected from infection by demolishing the current factory because it is unhealthy, dark and humid, and there is no separation between rabbits and 
workers to prevent infection. El Wali rejects the idea because it costs much. The factory needs ten million pounds to be rebuiltto be suitable for work and keep workers healthy.

In this play, El Saadawi discusses several concepts, such as altruism, conscience, sorrow and responsibility. She introduces the characters who represent the people of today's society and their different thoughts. The play's world is today's world and everyone chooses his role according to his own ideas. El Wali neglects and do not care about people who live below his social and economic levels and only struggle to remain at the top of power, no matter how much it costs. He represents the patriarchy of authority. When Dr. Fahim tells him what is happening in the factory, he chooses his personal interest over the interests of the workers

One form of abuse of power is to give false information about a situation. El Wali orders Dr. Fahim to inform the workers that there is no disease called Zarqaa in the factory. So that workers would not think of leaving the factory and escaping it, which would cause a disaster for the country. El Wali says: "Rabbits are wealth, our only capital; I do not have any doubt that they could be exposed to any danger". He adds: 
Our rabbit's wool has a good reputation everywhere. I don't want the workers to know anything, if they know, they will run away and the factory will be shut down. The workers will not think about the interest of the country, they do not have the spirit of sacrifice for the country. Is it correct Dr. Fahim? So, you should provide the workers with national awareness and they should remain above their own interests. ( I,iii,26, my translation)

The microbe makes the persons in authority expose their ugly faces to the world and revenge the poor until they enjoy watching them at the height of their impotence and poverty. They participate in killing human beings in full conscience. When Dr. Sharaf El Din and Dr. Tawfiq were working in the laboratory, they discovered this disease. Dr. Fahim told the authority represented in El Wali what was happening in the factory but the latter chose his personal interest over the interests of the workers. He did not pay attention to the affairs of the workers and ignored them. The workers for the authority are like dolls and puppets. The evil spreads in the events of the play as corruption does in the society.

El Wali believes that the death of four workers every month at a rate of fifty workers each year is small and normal 
number. It can be compensated by the number of applicants that reaches two or three thousands annually to the factory. He also sees that the number of labor force is great and the possibilities are limited, which indicates the presence of unemployment. El Wali believes that protecting rabbits is more important than protecting workers, as rabbits are the country's wealth and its only capital.

Dr. Tawfiq says:

In our country, human beings are cheap, Sharaf El Din, because they exist and are available such as the spare parts in the market at any time and at any price. When you lose a spare part you throw it and buy another one because the price of the new is cheaper than repairing the old $(\mathrm{I}, \mathrm{v}, 36$, my translation)

Dr. Tawfiq is an example to those who are cowardly living in the darkness of their imaginary ideas. When Dr. Sharaf El Din died, Dr. Tawfiq said:"I am a coward, I know that it is El Zarqaa and I am silent and I cannot say ....I want my children, Shuhdi, to live, eat and go to school, my children may be the reason, may be not the reason, I do not know, Shuhdi ... I am afraid, I am a coward". 
According to Dr. Tawfiq, there is a class of persons holding exceptional rank and privileges. He considers those the best or most able people in the state. He says:

We cannot build [a factory], but there are many buildings we can build. We build decorated houses such as palaces that respected people live in. This class of people is not similar to the cheap spare parts, as every part of them is expensive. Their houses are expensive. Their clothes are expensive. Their nails are expensive. The color of their nails is expensive. Their cough is expensive. When one of them coughs one cough, it costs him thousands of pounds. There are much money, Sharaf El Din, but there are priorities. You do not know what priorities mean, it seems that you have not studied planning" (I,v,40,my translation)

In addition, there are those who know the truth but do not utter it. For instance, Dr. Fahim who asks his previous students and his colleagues now, Dr. Sharaf El- Din and Dr. Tawfiq not to speak about the disease in the factory. Dr. Fahim does not tell the truth for Dr. Sharaf El- Din and leaves him to go to the factory every day. While Dr. Fahim was continued to act the wrong practices, Dr. Sharaf El Din proved his bona Fide stances with the sick workers in the 
factory every day . El Wali orders Dr. Fahim not to go to the factory to protect himself from disease because he represents a national wealth to the country.

According to Dr. Fahim, the adherence to the values is not sufficient reason to live a good life. He chooses the easy ways in his life to achieve his goals. He prefers to marry Tafida, a woman belongs to the aristocracy class because he finds the way to Dr. Nadra very difficult as she belongs to a poor class and her father is a worker in the factory.

Dr. Nadra works during her studying period in the university to be able to complete her study. She is appointed in the same factory with Dr. Fahim, his previous prof. in the faculty. Then she leaves the work in the factory as a doctor to work as a secretary in his office. Finally, the play ends with the regret of Dr. Fahim about his action and not to choose the right path. He understands and learns the moral lesson from her female student Dr. Nadra.

Dr. Fahim says: "The education we are taught in the schools, faculties, positions is not education. It is only just information we stuff in our brains in a similar way as we stuff rice into zucchini or stuff cotton into rough bags". He deeply regretted and asked Dr. Nadra to forgive him. Dr. Nadra left 
her family's house under the slogan of women's freedom and emancipation to marry a worker in the factory who dies as a result of the disease.

There are many people are cooperative not selfish as Dr. Sharaf El Din who continues to work in the factory and care about workers until his last breath. He believes Dr. Fahim when he says there is no Zarqaa. He considers Dr. Fahim his guide and model, but in fact he was deceived. After the succession of events, Dr. Sharaf El-Din died after the transmission of infection for him. He discovers the truth late. Sharaf El Din says hardly:

TAWFIQ., Dr Fahim is a liar, I understand him now. Why I did not understand him before. It is too late now. The chance has gone, Tawfiq. Also, the hope has gone (breathlessly) (II,iii,54, my translation)

Finally, there are those who utter the truth but are imprisoned. The male nurse, Shuhdi is the only character in the play who knows the living and working conditions of the workers and their families. He is an ordinary person accused of guilty since he wants to tell the truth about the spread of El Zarqaa disease in the factory. So, he is imprisoned because 
he refused to lie. He asserts that there is a disease in the factory and he wants to return to the factory to tell the workers the truth.

Shuhdi's pain is great at the personal level. He suffers abuse, multiple injuries and threats by a jailer who hits him with a whip, then, relaxes, spits on him, and returns to hit him again:

SHUHDI: the sting of whip does not hurt like the sting of pain and hunger. It hurts like a sting in the eyes of an orphan looking for a morsel in the dirt.

The jailer: my arms have dislocated and your blood spread on the ground and you still don't want to hear the words. Do you see what is on this ground? This is your blood.

Shuhdi (feels his body) : this is my blood, I don't know this is my blood. Strike me as you want.. Okay, I don't feel my body...

(The jailer beat him hard) (I,iv,59, my translation)

The jailer hits Shuhdi several times with a whip while he is lying on the ground in his cell to force him to admit that 
there is no Zarqaa in the factory, but Shuhdi insists that there is $\mathrm{Al}$ Zarqaa microbe:

The JAILER: say there is no Zarqaa

SHUHDI : there is

THE JAILER : no, there is not

SHUHDI : there is .. there is .... There is

He screams while saying madly: there is darkness (I,v,59, my translation).

The play ends with the regret of Dr. Fahim about his action and not to choose the right path. He deeply regretted and asked Dr. Nadra to forgive him. El Wali asks himself at the end of the play, "Why I am the last person to enter, why I am not in the foreground?" Personal interests rather than justice drive him to protect his own interests in the business. El Wali lacks the empathy or caring for others, viewing workers as "spare parts" to be bought.

El Wali shows indifference to their suffering and disease and treats them in an inhuman way. He is the epitome of patriarchy of authority that is characteristic to many egocentric businessmen. He loves himself too much and, is 
thus concerned with nothing but satisfying his own needs and fulfilling his own desires. Now, he realizes wisely that there is no difference between him and people. There is no difference between him and all human beings.

However, whether Al Zarqaa is disease or a threat, the poor workers are a symptom of a sick society. The example of the health system can be applied to all state services. Poverty induces unhealthy conditions of living which affect the physical integrity of people. Absence of State action to remedy poverty in society is in itself probably the worst violation of human rights. An examination of the play's relevance today reveals that the poor employment and discrimination against the workers still exist today.

El Saadawi pays attention to the good and bad conditions of the children in their country. The children have two pictures in El Saadawi's plays. On one hand, Horus in Isis, the son of the Egyptian sailor, is an ordinary child educated and protected by his mother. Isis distributes pencils and teaches the group of children how to write. These children represent the future of the country. They sing for Isis:

You planted the first tree in the land. 
you baked the first loaf of bread from wheat

and barley.

I wrote the first letter on paper.

I knew the first melody of justice and mercy.

Beneath your arms, my mother, I knew the truth.

Righteousness is above power and justice

is virtue. (II, I, 84)

On the other hand, El Saadawi was the first medical doctor to fight against the cutting of children under religious - cultural slogans. This ritual " deprive[s] millions of women all over the world of one of their basic human rights: the right to bodily integrity." (Imperialism and Sex in Africa,22).

Throughout her writing, El Saadawi has launched a campaign against this practice which she describes as a "cruel rite". She criticizes and condemns this social practice through Isis's comment:

Isis. How does the god Ra contradict himself when he says that he gave life to people and molded their bodies in the most perfect way, and then he orders the removal of parts of their 
created bodies in the name of circumcision or castration? ! And why does the law of castration and circumcision affect only slaves and women? (II, vi, 115)

In addition, many families of working poor cannot provide their children with the required economics means in Egypt. They suffer hungry and deprivation. In Al Zarqaa, the first scene in Act II expresses the miserable case of these children:

Light begins to cover the stage gradually. And the passing people begin to occupy the stage, everyone is running quickly to his work. No one sees the child sitting with his empty outstretched hand. A passerby throws a penny into the small, outstretched, empty hand without looking at the child and speeding up on his way. The light gradually dimmed on the stage. People gradually decrease until the theater is completely dark and becomes empty of pedestrians. All that remains is the little boy sitting in his place with his hand outstretched in front of him in the dark (II,I,47, my translation)

This child in this play represents the street children who need to live a good life. He suffers from poverty. He is in need to health care, food and clothes. These street children 
are time bombs and may be grown up to become easy tools in the hands of terrorists and terrorism.

El Saadawi supports her daughter's opinion that "the children should take the name of father and mother, that the name of the mother should have the same honor as the name of the father". Mona Helmi adds, "this will solve the problem of 2 million illegitimate children living on the streets in Cairo, with no human rights (because their fathers refused to give their names to their children). (Roza El Youssef, , 21 March, 2006).

Finally, in many instances in her writing, El Saadawi connects between the liberation of homeland and the liberation of human beings. She supports the idea of "Just" with an emphasis on the "human rights" of the marginalized people such the women and the poor. She seems to assert our need for human rights, not only for supporting our "sense of belonging" but also for asserting our ability to connect the women with her own hometown. El Saadawi's identification with the homeland, the river Nile, Arabic language/ literature continues to constitute a meaningful existence and powerful sense of belonging. Human rights seem mostly to connect El 
Saadawi to Egypt and to Egyptian women, from whom she feels estranged because of her controversial ideas. 


\section{$\underline{\text { Works Cited }}$}

Amireh, Amal. "Framing Nawal El Saadawi: Arab Feminism in Transnational World."Signs 26.1(Autumn, 2000): 215249.

Bagnole, RihabKassatly. "Introduction".The Dramatic Literature of Nawal El Saadawi. London: Saqi,2009.

Bakhtin, Mikhail M. "Forms of Time and of the Chronotope in the Novel: Notes toward a Historical Poetics." Mikhail M. Bakhtin: The Dialogic Imagination: Four Essays. Ed. Michael Holquist. Trans. Caryl Emerson and Michael Holquist 1981. Austin: University of Texas Press, 1990.

El Saadawi, Nawal ,- - - . Isis. Plays by Mediterranean Women. Trans. Ed. Marion Baraitser. Twickenham: Aurora Metro Publications, 1994.

- - . The Nawal ElSaadawi.Reader.Ed. Adel NewsonHorst:London: Z Zed Books,1997.

Genette, Gerard. Palimpsests: Literature in the Second Degree. Trans. Channa Newman and Claude Doubinsky. Lincoln: University of Nebraska Press, 1997. 
Gharbi,

Rajaa.

"International

Interview:

NawalElSaadawi." Off Our Backs, 1987: 17-18.

Gueye, Khadidiatou. '"Tyrannical Feminity' in Nawal El Saadawi's Memoirs of a woman." Research in African Literatures41(2010): 160-172.

Harlow, Barbara. Resistance Literature. New York: Methuen Press, 1987.

Hitchcock, Peter."Living the Struggle: Nawal El Saadawi Talks about Writing and Resistance."Transition: An International Review 61 (1993): 170-79.

Mehta, Brinda. Rituals of Memory in Contemporary Arab WorldWomen's Writing.Syracuse: Syracuse UP, 2007: 1523.

Smith, Barbara. "Racism and Women's Studies: All the Women are White, All the Blacks are Men, but Some of Us areBrave."Black Women Studies.Eds. Barbara Smith, Gloria T. Hull and Patricia Scott.New York: The Feminist Press, 1982: 48-51.

السعداوى، نوال .الزرقاء ـ القاهرة: مكتبة مدبولى ، 2006 . 